\title{
Brain, emotion and language.
}

\section{Theoretical perspectives applied to second language learning ${ }^{1}$}

\author{
ANA BLANCO CANALES \\ University of Alcalá (España) \\ ana.blanco@uah.es
}

\author{
CARMEN RODRÍGUEZ CASTELLANO \\ University of Technology (Jamaica) \\ carmen.Rodriguez@utech.edu.jm
}

\begin{abstract}
Second language teaching methods have undergone constant innovation since the mid-twentieth century. However, this has not brought the desired results, suggesting the need to address other crucial factors as yet unexplored and particularly to understand how the brain learns and how language functions in the learning brain. This article examines several schools of thought from brain science and the science of the mind from the perspective of their potential relevance to language learning. The task is not without difficulty, given the enormous volume of available knowledge, requiring not only a thorough analysis of the scientific production but also, above all, a precise selection of material that can be integrated into the field of linguistics applied to the teaching of language, both in terms of research and methodological approaches. We will analyze concepts, theories and paradigms related to the fundamental capacities of the brain, such as perception, emotion, memory and language, in order to better understand how they function in the second language learning processes of as well as raising a series of questions that could be usefully addressed by future researchers in the field of applied linguistics. Our interest is to reflect on how this knowledge can offer new theoretical frameworks on which to build more effective second language teaching approaches and strategies.
\end{abstract}

\section{Keywords}

Learning processes; second languages; brain; emotion; unconscious mind.

\footnotetext{
1 This study formed part of the research project Comunicación, emoción e identidad en la adquisición y aprendizaje del español como segunda lengua, funded by the FEDER/Spanish Ministry of Science, Innovation and Universities. State Research Agency. Project Project FFI2017-83166-C2-1-R.
} 


\section{Cerebro, emoción y lenguaje. Perspectivas teóricas aplicadas al aprendizaje de segundas lenguas}

\section{Resumen}

Desde mediados del siglo pasado, hemos asistido a constantes innovaciones en los enfoques de enseñanza de segundas lenguas. Sin embargo, esto no ha traído consigo los logros esperados, lo que nos hace pensar en la necesidad de atender a otros factores cruciales no considerados y, especialmente, comprender cómo aprende el cerebro y cómo es el funcionamiento de la lengua en ese cerebro que aprende. Este trabajo trata de revisar algunos aportes de las ciencias del cerebro y de la mente desde la perspectiva de su potencial relevancia para el aprendizaje de lenguas. La tarea no está exenta de dificultad, pues el volumen de conocimiento disponible es enorme, lo que exige no solo un análisis minucioso de la producción científica sino, sobre todo, una selección de precisa de la información susceptible de integrarse en el campo de la lingüística aplicada a la enseñanza de lenguas, tanto en trabajos de investigación como en enfoques metodológicos. Analizaremos conceptos, teorías y paradigmas relacionados con las capacidades fundamentales del cerebro, tales como la percepción, la emoción, la memoria o el lenguaje, con objeto de comprender mejor su funcionamiento en los procesos de aprendizaje. Nuestro interés es reflexionar sobre cómo este conocimiento puede ofrecernos nuevos marcos teóricos sobre los que desarrollar enfoques y estrategias de enseñanza de segundas lenguas más eficaces.

\section{Palabras clave}

Procesos de aprendizaje; segundas lenguas; cerebro; emoción; mente inconsciente.

Recibido el 22/08/2021

Aceptado el 10/11/2021 


\section{Introduction}

Recent decades have witnessed increasing research interest in exploring and understanding the human brain and the mechanisms by which it works. Current technology has now rendered it possible to penetrate neuronal networks and observe their neurophysiological (EEG and MEG) and functional (fMRI) activity, yielding discoveries of enormous importance and impact in many areas of knowledge. Aspects such as perception, memory and language — all interrelated in the learning processhave benefited greatly from the abundance of studies.

Neuroscientists are attempting to unravel the complexity of neural networks and obtain results that will allow us to understand the nature of the human mind. Their findings depict these networks as connected systems that explain the different physiological, emotional, perceptual and cognitive responses involved in learning processes. Knowing about these systems of connections helps us to understand the dynamics of second language learning and to develop teaching methods and strategies consistent with the physiological mechanisms involved.

In the field of linguistics, interest in the brain and the mind has spurred a great deal of research into the bilingual mind, defining this broadly as the coexistence of languages, regardless of their mastery or use. Much of this research has focused on linguistic processing from the perspective of both behavior and the brain alike. The sum of both perspectives is providing an exhaustive description of the linguistic acts investigated, and more importantly, is yielding widely accepted answers to the major questions concerning acquisition (importance of the critical period, required amount of exposure to the L2, correlation between degree of competence and skills), processing (differences between syntactic and semantic processing, strategies used, processing of anomalies) and the use of two or more languages and its impact at both the brain and cognitive level (see García \& Suárez, 2016).

All this knowledge is bringing us closer to a better understanding of the neurophysiological and cognitive bases of language learning, which will undoubtedly facilitate the development of more effective teaching methods.

Here, we shall review some of the findings from the neurosciences that are particularly relevant to language teaching and learning. This will entail analysing issues such as the close relationship between the brain, the body and the environment; the role of perception and sensory experience in memory and the representation of reality; emotion as the main driver of learning and identity construction; the unconscious mind and decision-making; language comprehension; and the attribution of meanings and their distribution in the brain. We shall reflect on the implications of these findings for second language teaching and raise some questions that still need to be addressed in future research on linguistics applied to language teaching. 


\section{Brain, body, mind and environment}

\subsection{The brain and the mind}

Our ability to perceive, think, remember, feel emotion and be aware of our own existence is the result of the enormous activity that takes place in the brain. All these capacities constitute mental phenomena and are the essence of what we call mind.

All internal and external stimuli reach the individual's brain, where they are integrated and then interrelated with stored cognitive and emotional experience. There too, the individual's corresponding response is generated. The mind emerges from conscious and unconscious activities and processes, especially those of a cognitive and affective nature, as shown by -or in relation to- subjective experience (Giménez Amaya \& Murillo, 2007: 613).

One of the ideas proposed in neuroepistemology - a discipline that studies the neuronal basis of the mechanisms of knowledge as a result of humanity's evolutionary needs and adaptation to the environment - is that we should view the mind as the product of a brain designed to see, capture, perceive and assimilate reality in a specific way. This implies that the evolution of the brain has been and remains linked to the development of cognitive abilities that ensure our adaptation to the demands of the environment. One example of this is language, a capacity developed in response to our need as social beings to communicate. This capacity, together with others such as duality, substantiality or causality, time and space, involves our cognitive mechanisms (Rubia, 2009). Consequently, studies of the processes involved in language, our behavior or the acquisition of knowledge about reality should start from the physiological structures through which reality is perceived.

\subsection{Together, the brain and the body construct reality}

Perception, memory, learning and language are all simultaneously physical, cerebral and mental acts. We can see how they take place in the brain's circuitry, although they are experienced subjectively (mentally) and are also very much conditioned by bodily experience, which is what finally determines the representational schemata intrinsic to the wiring of the brain (Tomasino \& Rumiati, 2013).

Millions of neural and biochemical circuits connect the brain to the body, which receives external information through its sensory receptor organs. This information may be perceived via any of the senses (e.g. sight, smell, touch) and reaches the brain through a series of nerves that ascend from all parts of the body, like highways responsible for transporting certain types of information. Upon entering the brain, each of these pathways makes several stops at a series of intermediate stations, which modify the information. From there, the pathways branch out to penetrate the depths of the cerebral cortex, where they gradually intertwine with regions responsible for processes related to cognitive functioning, memory, decision-making and movement, thus incorporating perception into brain functions and processes. Besides these 
ascending sensory pathways, there are also many descending neural pathways that modulate and condition perception as it happens. These channel the powerful influence that learning, language and expectations exert on perception.

The body also receives internal information from the interoceptive senses, which provide the brain with a more complete representation of the sensory world. Thanks to interoception, the brain generates a representation not only of its own body, but also of the space that body occupies in the environment, the actions it performs, those performed by other individuals and its own mind. We are referring here to senses such as pain, temperature, hunger, thirst, position and movement.

These findings illustrate the importance of our sensory functions in understanding and constructing our referential universe. There is no question that we represent the world through language, but we can only do this only once that representation has been perceived and experienced. This raises the question of how our sensory perception could contribute to second language learning, and what results might be obtained if we systematically leveraged our sensory capacities — so intimately linked to mental processes - as mediators of learning and as channels that transport and modulate linguistic information. This would entail associating new content with different types of sensory experience, as occurs with the mother tongue.

\subsection{The environment is part of the mind}

Damasio (1994: 15) has contended that besides being a life support for the brain, the body is also an inseparable part of the mechanisms of the mind. The body not only receives external stimuli, but also regulates our perception of them (our body structure conditions the way we perceive). Consequently - he adds - the organism as a whole interacts with the environment: the interaction is never that of the body alone or the brain alone. Moreover, mental operations involve the structural and functional whole, not only the brain: mental phenomena can only be properly understood in the context of an organism's interaction with its environment (Damasio, 2010).

Thus, the human organism interacts as a whole with the environment. Furthermore, we represent ourselves in the environment as if it were a part of ourselves. Psychologists call this outer space peripersonal space: "It is a construct your brain actively creates as part of your mind's body [...] the space immediately around you is literally a part of your body." (Macknik et al., 2010: 108). Several experiments have shown that objects inside this peripersonal space are processed differently to those that are not. Thus, the possibility of grasping them, for example, activates motor areas of the brain that are not activated if they are out of reach (Preston, 2013). In the human organism, the brain and body perceive and understand the world in unison, and the organism extends beyond itself to incorporate its most immediate surroundings (Noë, 2010).

Brain, body and environment work together to represent the reality we perceive and conceive. This unitary organism, in which the sensory receptors are intimately connected to both the environment and mental mechanisms, interactively constructs 
our reality (Mora, 2013). All this is accompanied by a very well-structured language which, together with the previous elements, enables the emergence of the self - self-consciousness - that becomes conscious in our being and in that of others (Damasio, 1998). In short, we have the potential capacity to perceive the world through our sensory receptors, but this perception depends on our learning and our experiences and with it we construct, through language, a subjective reality.

In view of this, we can no longer conceive of the student as an entity possessing a brain whose mental activity enables that person to learn, independently of the body and the environment, which at best function as external collaborators. A better image would be that of an individual whose mind expands into a whole constituted by brain-bodyenvironment, in an amalgam of sensory and emotional connections. This conception of the learner also aligns with the assumptions of embodied theories of cognitive sciences, according to which knowledge arises from the constant interaction of organisms with their environment. This idea contrasts with previous ones that constructed knowledge as the reception of neutral information onto which individualized meaning is inscribed (Di Paolo, 2015). In the embodied view of language, linguistic meaning conceives organisms as corporeally situated in the world; it is from here that the meaning of words emerges.

These assumptions lead us to think that in language learning, exposure to the L2 corpus or connectionist theories, which predict a transfer of knowledge from L1 to L2 due to the pre-existence of a well-organized neurolinguistic system (MacWinney, 2001), is not enough. On the contrary, they bring us closer to the idea of integrating activities that implement sensory perception and project the interaction of the learner with the environment. Examples of this can be the re-creation and evocation of mental images which activate different motor and sensory areas of the central nervous system; innertalk techniques which project the learner's mental image in interactions embedded in an experiential environment; or motor simulation activities which allow access to the field of meaning and are based on the theories of motor resonance and the anticipatory nature of the brain (Fischer \& Zwan, 2008; Pulvermüler \& Fadiga, 2010).

\section{Memory and its neuronal distribution}

Our brains are shaped by all our experiences and learning (Bransford et al., 2003; Posner \& Rothbart, 2005). Even without being aware of it, we are incessantly sculpting our brains. The uniqueness of experiences affects each particular brain in such a specific way that not only is every brain unique, but also every moment of its existence is unique. The phenomenon of continuous neural modification, strengthening, weakening or removing existing connections and generating new ones, is known as neural plasticity (Carlson, 1996: 399). This is a basic process for good memory function, defined as the nervous system's capacity to encode, store and recover the numerous stimuli that reach and shape us.

The hypothesis of the central role of neuronal plasticity in learning mechanisms was advanced by Ramón y Cajal in the late 19th century: he argued that modifications 
in the synapses formed the basis of learning and memory. This idea has been extensively developed and is today one of the cornerstones of neuroeducation.

Current research on memory has undergone a rapid and major turnaround in consequence of the shift from modular theories of the mind to models of widely distributed but partially overlapping, interconnected and interactive neural networks, mainly in the cerebral cortex. As a result, experimental models aimed at locating memory in very specific areas of the brain have been combined with others that consider it a property of all neural networks and systems. This approach has been reinforced by the discovery that there are specific neural networks for different types of memory, prompting the development of new models of neural architecture that combine the characteristics of interactive, distributed neural systems throughout the brain with those of cortical domains specific to certain types of memory (Baddeley et al., 1995; Goldman-Rakic, 1999; Petrides, 2000; Fuster, 2014).

It was the neuroscientist J. Fuster (1995) who first conceived this new paradigm, a hierarchical model in which the different types of memory are organized into two large groups - perceptual and executive- depending on whether they are acquired by areas responsible for storing sensory information - perceptual memory - or by the motor areas responsible for behavior - executive memory. Perceptual memories are mainly distributed in the posterior part of the cortex (the temporal, parietal and occipital lobes), and include sensory experiences and all memories and knowledge acquired by means of these. Executive memories correspond to the knowledge and memory of actions acquired by the organism through its experience of acting on the physical and social environment, and are mainly distributed in the frontal cortex. At the lowest, most basic level, is the primary motor cortex in which an individual's various motor and executive memories are formed; at the opposite extreme are behavioral patterns, creativity and decisions.

Since memory is at the heart of all learning, this new concept diverges even more widely than its predecessors from teaching models fundamentally geared towards information storage, in which, regardless of its nature, content is perceived, processed and stored artificially, without ultimately leaving any "trace" in the brain. The various types of memory are related to the kind of information concerned, how it is acquired and its function; therefore, the ways of acquiring knowledge should be related to the structural and functional complexity of memory. If this is a large network of connections distributed throughout much of the brain that interacts with many other dimensions (perception, experience, emotion, language), then the failure to employ teaching models that facilitate and accommodate the natural operation of memory is incomprehensible. In the case of language teaching, this is even more striking and contradictory, as memories are "labelled" with language, so that some of the conceptual representations retained within a memory are typically encoded with the language in which they were experienced (Isurin, 2017). If there are no genuine experiences in the language being learnt, what semantic and representational values can be attributed to the new linguistic signs? Where are they stored, if it is not possible to differentiate psychobiological areas of acquisition? 


\section{Emotion and learning mechanisms}

\subsection{Emotion}

"Emotion is an all-pervasive mental phenomenon. There is not a single moment of the day when we do not experience some kind of emotion, however faint, even during sleep" (Carretié, 2011: 105). Emotions can be viewed as a series of physiological, cognitive and motor changes that arise from the conscious or unconscious appraisal of a stimulus, in a particular context and in relation to the individual's objectives at a given time of life (Freeman, 2000; Lewis, 2005; Scherer, 2005).

Emotion is an organized response to an external event or an internal occurrence (e.g. a thought, image, fantasy or behavior). It is generated by a perceptual process followed by an appraisal that triggers a neuropsychological response or a cognitive behavior or attitude; in the case of a behavior, this arouses a predisposition to action (Bisquerra, 2003).

Emotions play a fundamental role in survival, maintenance of the species, social relations and communication. They also fulfil a motivational function, predisposing us to constantly repeat behaviors associated with positive emotions.

Mora (2017) has contended that our emotions are our identity and that nothing that happens in the cerebral cortex occurs clinically, devoid of an emotional filter. Emotions are intimately linked to our cognitive and learning processes.

The limbic brain and brain stem - and within them, the orbital prefrontal cortex, the amygdala, the hippocampus, the hypothalamus and the ascending reticular activating system - are the fundamental brain areas that house the neural circuits which encode emotion (Saavedra et al., 2015). This process can be summarized as follows: everything that is perceived by the senses is first analyzed in specific areas of the cerebral cortex, except in the case of highly emotional stimuli, which take shortcuts and go directly to the subcortical areas that manage emotion (Carretié, 2011). Next, sensory perceptions pass from these specific areas to the filter of the emotional system, where they are labelled as good or bad, attractive or unattractive, interesting or neutral. Now colored with emotional meaning, this information then reaches the association areas of the cerebral cortex, where mental, reasoning and thinking processes occur and complex executive functions are formulated. Finally, it arrives at the hippocampus, which records the trace of what was perceived and learnt (Mora, 2017: 42).

\subsection{Emotion and language learning}

Without emotion, there is no learning. Any learning process involves changes in the synapses that make neuronal connections possible (Zull, 2002; Mora, 2013). These changes do not occur in a vacuum. Instead, they depend to a large extent on the type of experience and the environment in which it took place. At the same time, as Zull (2002) has noted, two other elements are essential: practice and emotion. Practice prompts frequent activation of neurons, triggering them to develop and interconnect, creating 
synapses and modifying existing neuronal structures. This process of connection and modification requires emotion and its chemical components (dopamine, serotonin, adrenaline). "Learning is connected to emotion when the experience of learning is sensorially rich and engages learners not only from the neck up, but also in their cognitive, affective and physical dimensions" (Ávila, 2015: 3).

Since languages are highly emotional products, it is particularly important to involve emotion in language learning. In the case of mother tongues, emotion is inherent in language acquisition and development. In consequence, when we use our mother tongue, our emotional tone is strongly connected to the message and the context. Since we are emotional beings, an emotional tone always accompanies our acts or our sense of being (Damasio, 1998). The self that acts or observes does so immersed in an emotional tone. Thus, in the scenario of second language learning in contexts of immersion, the linguistic cognitive processes are aligned with the emotional and sensory experience of the self that is acting and observing; however, in the classroom, the message of words and expressions contains no emotional resonance. The classroom is an academic learning context where cognitive and metacognitive strategies are applied to practice, memorize and learn language content without any emotional connection. The L2 learner observes the target language as a linguistic object. Consequently, the referential emotional and identity content of the words and expressions in the L2 remains incomplete, since the emotional component of a language is located in the linguistic process (linguistic experience) and not in the process of learning the linguistic object.

This school of thought underlies The Emotional Context of Learning Theory proposed by Harris and her team (Harris et al., 2006), whereby words and phrases acquire a distinctive emotional resonance when they have been learnt, or are habitually used, in a specific emotional context. Use of the language in these contexts endows it with emotionality because human experiences are learnt and stored in a contextdependent manner. This view is consistent with trace theories of episodic memory (Hintzman, 1986), encoding specificity (Tulving \& Thompson, 1973) and languagedependent recall of autobiographical memories (Marian \& Kaushanskaya, 2004, 2008). According to Harris, age of acquisition and level of competence are not, in themselves, the factors responsible for a greater emotional response in the L2, but are instead subsidiary to highly emotional contexts which enable the language to be experienced as something emotional. These are the usual contexts for childhood learning, and those with a high level in the L2 are also likely to have experienced many situations with emotional intensity, but those with a low level will have a very limited repertoire of experiences in their second language.

\subsection{Emotion, feelings and language teaching}

Although emotion and feelings are closely linked, they each involve different sections of the brain. According to Damasio (1994, 1998, 2010), emotions precede feelings. Emotions are the body's responses to an emotionally competent stimulus, i.e. 
an object or event of biological importance. Damasio, however, also points out that all objects have a potential link with emotions and that most objects, in our interaction with the world, entail some emotional reaction. He thus highlights the omnipresence of emotions in our development and, consequently, in our everyday experience, as well as its strong connection with the body. Feelings, on the other hand, are the subjective, stable and more or less lasting experiences of emotions, and are devoid of somatic markers. When the results of emotions are mapped in the brain, feelings arise, which are images or representations of the emotions and their results in the organism.

Kramsch (2009) points out the relevance of the distinction between emotions and feelings in L2 to understand learners' reactions to the target language. She points out that "the sense of continuity of the self comes from being firmly grounded in the body and its neurological processes. It is precisely this continuity that foreign language learners lack" (Kramsch, 2009: 69). Contending that emotions are not atomized entities, Benesch (2011) foregrounds the importance of their social dimensions such that they might better be integrate into the second language classroom. Regarding the emotional bonding of the organism with objects (Damasio, 2010; Agmed, 2010), Benesch points out the relevance of knowing the emotional relationship of L2 learners with the objects in the environment so that teachers can more easily engage their social world.

Emotional attachments between people and objects are not necessarily conscious and the learner does not relate them to his or her own L2 learning process. These emotional attachments, which are closely related to the semantics of the language referring to those objects, are not what Damasio describes as feelings. However, they are present and fill the words with meaning. This particular vision of the student's space and the innate emotional reactions generated by the elements of their environment should be an integrating tool of identity, motivation and attention in the dynamics of teaching. Moreover, it is a reference to favor the full construction of meaning in L2.

Drawing a distinction between emotion and feeling is important to formulate teaching methods that involve both processes. Emotions arise as hidden processes inseparable from our cognitive functions and do not always pass into consciousness, whereas feelings are related to the sensation of conscious experience.

Some L2 teaching strategies are based on engaging the affective dimension (feelings/consciousness) but not necessarily the emotional dimension (physiological/preconscious or unconscious process). Many of the L2 teaching methods that have emerged since the late 20th century (functional, communicative, task-based and humanistic approach) address the affective dimension, reinforcing positive feelings and affective factors in the learning process. They are supported by numerous research studies that demonstrate the important connections between positive evaluation of stimuli during language learning and improved development of communication skills. This can be seen in studies on affectivity in general (Arnold, 2000; Dörnyei \& Murphey, 2003; Stevick, 1998; Williams \& Burden, 1999), as well as in others that investigate its role in motivation (Dörnyei, 2005; Lorenzo, 2004), attitudes (MacIntyre \& Charos, 1996), self-esteem (De Andrés, 2000), self-efficacy (Boza, 2002), anxiety (Rubio, 2004; Young, 1999). All these works focus their interest on aspects related to context and 
behavior in the learning process without delving specifically into neuropsychological and neurobiological issues.

A review of academic programs, teaching materials and teaching action shows us that teaching strategies in L2 are generally geared towards stimulating motivation, reinforcing positive affective factors (self-esteem, safety, pleasure, satisfaction, joy), avoiding negative ones (anxiety, distress, low self-esteem, stress, boredom) and leveraging the emotional content of music, films, texts and interaction (group work, drama, etc.). However, they do not attend in the same way to this other concept of emotion as an unconscious physiological response linked to cognitive functions and motivated by external, environmental (linguistic and sensory information) or internal stimuli. Neuroscience offers new possibilities for working with the stimuli that trigger emotional responses linked to the cognitive functions involved in learning and opens up a wide field of study for the development of teaching strategies.

\section{The unconscious mind}

\subsection{Thought systems}

Current cognitive psychology depicts the unconscious mind as an amazing system capable of almost instantaneously processing numerous items of information, something that would be impossible for our conscious mind. This unconscious mind performs high-level cognitive mental functions and is responsible for making almost all our decisions and performing the important mental processes involved in our learning (Rubia, 2009; Bargh 2017). As regards the learning process, the most interesting facet of this unconscious dimension is its role in aspects as important as motivation, representation and behavior.

According to Kahneman (2011), we have two types of mental processing, System 1 and System 2. The first corresponds to our unconscious cognitive processes and is an associative, automatic system capable of processing high-level cognitive information. The automatic operations of System 1 generate complex patterns of ideas, while at the same time functioning rapidly with little or no effort and no sense of voluntary control. Meanwhile, the second corresponds to our conscious self and allocates attention to effortful mental activities. The operations of System 2 are often associated with the subjective experience of agency, choice and concentration. System 1 never rests, whereas System 2 is normally in a low-effort mode. The two systems share the work, optimising performance and rendering us more efficient. Kahneman argues that System 1 constantly generates suggestions for System 2 in the form of intuitions, intentions, impressions and sensations. If these suggestions are accepted by System 2, impressions and intuitions become beliefs and impulses are converted into voluntary actions.

One very important characteristic of System 1 is its associative capacity. When we receive a stimulus, for example the visualisation of two words with no apparent relationship, our System 1 automatically creates an association, and ideas and images come to us involuntarily. This association also triggers physical and emotional reactions, generating, for example, gestures and facial expressions of like or dislike. In 
turn, these reactions intensify the feelings associated with each word, generating or reinforcing compatible ideas. Then, the ideas evoked by the stimuli cause many others to cascade through the brain. All this happens rapidly and simultaneously, evidencing a pattern of self-reinforcement of cognitive, emotional and physical responses (Kahneman, 2011:73). It is precisely this that has led cognitive psychologists to assert that the mind is part of the body, not just of the brain; in other words, that the body also thinks (see Calvo \& Gomila, 2008; Glenberg et al., 2008).

In L2 learning, learners are exposed to many diverse stimuli with which they create contexts for interpretation and association that subsequently influence their attitudes, appraisals and motivation. Images, characters, sounds, sensations, stories, topics and facts are all processed and stored, and then form the basis from which decisions are constructed. How do these elements impact on learning? To what extent is the determination to continue influenced by learner engagement and effort? It seems necessary to investigate this unconscious mind that makes decisions and to study how it impacts on language learning and how we can engage it.

\subsection{Decision-making}

Constant decision-making is inherent in daily human activity, and learning processes are no exception. Contacting native speakers, maximizing learning time, managing effort, targeting priorities efficiently, engaging in scenarios conducive to language acquisition, reinforcing practice and travelling to a target language country are all decisions that substantially affect L2 learning outcomes.

A greater knowledge of the mental processes involved would help us generate educational scenarios that reinforce good decision-making. Several studies in neuroscience have shown that the unconscious mind makes decisions before we have the conscious experience of deciding (Libet, 1985; Soon et al., 2008). In other words, our conscious experience tells us that we are making a decision when in fact this perception only comes after the decision has already been made. The surprising thing about these studies is not only the finding that we are unaware of the true causes of our actions, but also the enormous speed and proficiency with which the left hemisphere creates and invents causes for our conscious mind to explain our actions. A plausible reality is more important to our brain than reality itself (Rubia, 2000). Thus, perceiving ourselves as agents of our decisions is a phenomenological experience and a cognitive capacity of our brain that does not necessarily correspond to reality.

If we take these findings into account, we can look for some causes that influence the unconscious mind of learners and that are behind their behavior and decision making. We have to keep in mind that it is not a single conscious mind that attends the classroom but two minds that act simultaneously and whose operations interact and process information based on external and internal stimuli. Two minds cannot be separated because they process information in unison.

Not considering the capacity of our learning system as a whole can lead us to act blindly and provide stimuli and information that may work against our goals. Thus, we 
could be including stimuli (conceptual, visual, etc.) that capture non-conscious attention without us knowing it is occurring. This would not be hidden or subliminal content, but content that, although not operative for the conscious mind, is operative for the hidden mind. The unconscious has a great associative capacity; classroom stimuli can create associations that help develop cognitive learning mechanisms without us being aware of it, or that guide decision-making. Remaining on the sidelines of the capacity and constant activity of the unconscious mind leads us to waste its relevant role in the learning processes and to implement, due to lack of knowledge, actions that play against us, that is to say, that lead us to make decisions that are inadequate for our interests. The problem lies in the fact that we have a partial vision of the learner and of ourselves, a single vision, which corresponds to the phenomenological experience of the self that feels itself to be and of a self with a will.

These results are very revealing for the field of teaching and learning. We now know that it is important to transcend the learner's conscious mind and implement certain actions (reorientation of cognitive biases, sensory stimulation, linguistic content, emotional capacity, etc.) which generate mental mechanisms that do not pass into consciousness but are responsible for behaviors and decisions that play a crucial role in the learning process.

Neglecting the function of the unconscious mind in learning also implies failing to pay due attention to stimuli and content that it may process to our advantage or disadvantage. Hence, teaching content and strategies may clash with academic objectives, for example, generating cognitive conflicts that would be detected and recorded as aversive experiences, avoided by the anterior cingulate cortex (Carretié, 2011), thus activating unconscious avoidance learning mechanisms and impacting on decision-making. In sum, remaining oblivious to the function of unconscious processes in our attitudes, judgements, behaviors and decisions limits the efficacy of teaching strategies and approaches.

\section{Language and the construction of meaning}

\subsection{Language networks and maps}

One of the great challenges of neuroscience applied to linguistics is that of discovering how the nervous system endows words with meaning and establishes relationships between words and the things and concepts to which they refer. Here, the cerebral cortex is fundamental because it is involved in learning associations, and thus controls construction of the word map that -it has recently been discovered - is distributed throughout the cortex.

This first semantic atlas of the brain was the work of a group of scientists at the University of California, Berkeley (cf. Huth et al., 2016). They asked seven people to listen to various stories from a radio programe for more than two hours while their brain activity was monitored and recorded by functional magnetic resonance. This enabled the scientists to map semantic representations of the words in each individual's brain. Then, using an algorithm to analyze the common characteristics of the seven 
individual maps, they created a general semantic atlas. Their results confirmed the initial hypothesis that the semantic system is widely distributed throughout more than a hundred different areas in the two hemispheres of the cerebral cortex.

Although the authors acknowledged that common experiences in the participants' lives may have contributed to the observed distribution of words in the brain, their results nevertheless corroborate those of other studies of the neural representation of words, which suggest that each word is represented in our cerebral cortex by a network of strongly interconnected neurons that is activated in its entirety every time we activate that word in our mind (González Álvarez, 2007). This network connects neurons in language areas with other networks in areas that process information about referents and are formed by the use of words in the context of objects and actions.

There is ample evidence to prove this. A classic example is the results obtained by Pulvemüller (Pulvermüller, 2005; Pulvermüller et al., 1996; Pulvermüller \& Fadiga, 2010), which shows that visual words such as whale or zebra activate posterior networks responsible for visual processing, whereas action words (e.g. hammer, scissors, grip, draw kiss, chew, kick, walk, run) activate networks for motor function. The same applies to color words or olfactory words, which activate parts of the brain close to the areas involved in color or odor perception (Martin et al., 1995; González Álvarez, 2007). In all cases, of course, the cortical language areas around the left lateral sulcus (the perisylvian area) are also activated.

Thus, we can state that language processing also involves sensorimotor systems, that is, it is mediated by implicit motor simulations and shares a common neural substrate with real motor processing (Baumeister et al., 2017; Buccino et al., 2005; De Grauwe et al, 2014; Fischer \& Zwaan, 2008; Foroni \& Semin, 2009; Glenberg \& Kaschak, 2002; Hauk et al., 2008; Quené et al., 2012; Meteyard et al., 2012; Moseley et al., 2011; Winkielman et al., 2008; Zwaan \& Taylor, 2006).

The motor and somatosensory information about the referent is interwoven with the word's phonological information and forms part of its meaning, which suggests that the meanings of words are not located in specific areas of the brain specialised in their processing, but rather that neural representations of words are widely distributed throughout the cerebral cortex (González Álvarez, 2007).

In linguistics, meaning has always been viewed as something abstract and unconnected to physical sensations or motor actions. However, research has demonstrated that the brain incorporates all this bodily, perceptual and motor information into the construction of meaning. Thus, when we learn a word, not only are the circuits responsible for its phonic categorisation activated, but also other areas responsible for the sensory and motor information derived from our experiences with the referenced object. This almost simultaneous co-activation drives the creation of lexical networks that incorporate these sensorimotor components as part of the meaning.

These findings have major implications for second language learning, prompting us to rethink the way in which learners construct this new code in their brains, especially in formal, non-immersive teaching contexts, which are the most common. In 
this sense, it would be necessary to think of contexts and learning situations that allow language learners to sensorially perceive the new vocabulary they are incorporating, to experience in communication the use of the terms or to generate real and experiential associations. To this end, it will be necessary to develop didactic proposals in which meaningful communicative interaction, experiences, movement, and the diversity of spaces and stimuli occupy a prominent place.

\subsection{Meaning and language comprehension. The embodied theory of language}

Similar conclusions have been reached by researchers in the field of cognitive psychology exploring the nature of meaning and language comprehension. These have suggested that meaning and conceptualisation are "corporeal" or "embodied" processes and that language comprehension involves mental simulation of the objects, events or situations described (de Vega, 2005). Comprehension of a word or a sentence activates visual, auditory, motor or emotional processes to represent the referents (i.e. understanding implies a mental simulation of the experience). Thus, language comprehension involves a resonance in or reactivation of cortical areas that normally deal with perception, action and even emotion.

Language acquisition studies have also suggested that learning linguistic meaning is closely linked to perception and action. Children learn action verbs such as grab, pull, put, take away, etc., while performing the corresponding actions themselves in context. The same applies to the names of objects, which children associate with immediate perceptual experiences in their environment. This close association between patterns of experience and language not only enables us to learn the meaning of words, but undoubtedly contributes to establishing reverberant circuits in the perceptual and motor areas that are reactivated when language is encoded (de Vega, 2005:157).

What happens in the case of second languages? Are they felt and experienced in the same way, and are they embodied to the same extent as mother tongues are? The results of Foroni (2015) and Foroni \& Semin (2013) suggest that somatic correlates of emotional expressions are weaker in an L2, as a consequence of weaker semantic connections. Baumeister et al. (2017) also observed reduced neural activity for the L2 and general differences between the two from an embodiment perspective, leading to the suggestion that while emotion processing in the L1 is based on embodied simulations, this is not the case in the L2, or at least it is not so clear that this is the case. What underlies these differences has to do with how emotions are experienced and learned during childhood, a very different context from L2 learning. A native speaker's experience promotes the establishment of strong action-perception links (Pulvermüller \& Fadiga, 2010), determinant in language comprehension. However, an L2 speaker may not rely on the same mechanisms (Pavlenko, 2005). Acquisition of native language words usually occurs together with the body movements and actions to which they refer and involves information received from all sensory modalities (Pavlenko, 2005). Formal L2 learning usually takes place in an artificial environment without significant 
involvement of most sensory modalities, which may result in less rich and direct associations. This is in line with the idea that different L1 and L2 socialization histories reflect on different degrees of embodiment (Semin \& Smith, 2008; Dewaele, 2008; Caldwell-Harris \& Ayçiçegi, 2009; Pavlenko, 2005; Sutton et al., 2007).

\section{Final reflections on teaching and learning second languages}

All the elements of language are intimately linked to an individual's cognitive and emotional development and experiences in his or her surroundings. Learning new words activates not only the circuits responsible for their phonological and articulatory form, but also other areas responsible for the sensory and motor information derived from our experiences with the referenced object. This almost simultaneous co-activation drives the creation of lexical networks or neural networks, which incorporate these sensorimotor components as part of the meaning (González et al., 2006).

Hence, one can argue that all the words in our mother tongue carry a meaning that provokes an emotion. There is no linguistic meaning that is not sifted through emotion. But what about second languages? Do learners experience emotional states when they visualise or perceive words in the target language? Numerous studies have indicated that when this does occur, it happens to a lesser extent and with less intensity (Altarriba \& Santiago-Rivera, 1994; Anooshian \& Hertel, 1994; Bond \& Lai, 1986; Dewaele, 2004; Dewaele \& Pavlenko, 2002; González-Reigosa, 1976; Marian \& Neisser, 2000; Pavlenko, 1998, 2002; Schrauf, 2000; Schrauf \& Rubin, 1998; Harris et al., 2003, to cite just a few examples). Thus, when an individual starts to learn a second language, each word is located like a satellite outside his or her personal identity. Current teaching methods do not deploy the elements necessary to endow meaning to every word and sentence in the target language.

The meaning of words remains incomplete without emotional factors, and these come via the sensory receptors, which perceive what the individual experiences. There can be no meaning without experience, and the simple transfer of a word from one language to another does not imprint that experience on the new word. Our experience is linked to our identity, and both form constituent elements of the development of linguistic competence in another language.

This suggests the need to design teaching approaches that relate classroom activities to the experiential self, so that L2 words take on a meaning as part of the learner's identity. In short, this would entail enabling conscious and unconscious associations of words and linguistic context with the stimuli in our multisensory environment and with our emotional identity.

In the initial stages of L2 acquisition, the learner is exposed to a very limited linguistic corpus of a functional nature based on information transactions that correspond to basic needs. The language is learnt from an instrumental point of view and students find themselves without sufficient linguistic competence to express their emotions or self. Furthermore, the "grammar packages" assigned to each level, which are swathed in functional and paralinguistic objectives that are likewise packaged 
according to level, erroneously associate basic personal information with a supposed expression of the student's identity. This personal information is devoid of emotion; it labels rather than individualizes, generalizing the individual within a class. This prevents the essential construction (or reconstruction) of the self in the L2.

As a cognitive and emotional activity, language learning is subject to the appraisal of stimuli in several dimensions: novelty and familiarity, importance of the goal or need, ability to cope, social image and self-image (Scherer, 1984). We need to know how these appraisals impact on the decisions and behaviors required to invest the necessary effort and commitment. Similarly, we need to know how emotional factors, beliefs and values influence the creation of appraisals - negative or positive - of the language, the learning process and related elements (e.g. speakers of the language, culture, etc.). Our emotions, beliefs and identity, and consequently our decisions and actions, are to a large extent the result of unconscious processes based on emotions.

Languages are constructions through which individuals show who they are, what groups they belong to, how they understand reality, what they feel, how they behave and so on; in short, language enables individuals to construct and transmit their sociocultural, linguistic and emotional identity. We do not simply store languages; we experience them, perceive them, feel them and act through them.

\section{Bibliographic references}

AHMED, S (2010). The promise of happiness. Durham, NC: Duke University Press.

ALTARRIBA, J.; SANTIAGO-RIVERA, A. (1994). Current Perspectives on Using Linguistic and Cultural Factors in Counseling the Hispanic Client. Professional Psychology Research and Practice, 25(4), 388-397. DOI: 10.1037/0735-7028.25.4.388

ANOOSHIAN, L. J.; HERTEL, P. T. (1994). Emotionality in free recall: Language specificity in bilingual memory. Cognition and Emotion, 8(6), 503-514. DOI: 10.1080/02699939408408956

ARNOLD, J. (2000). La dimensión afectiva en el aprendizaje de idiomas. Madrid: Cambridge University Press.

ÁVILA, J. (coord). (2015). Didáctica de la emoción: de la investigación al aula de ELE. Marco ELE. Monográfico.

BADDELEY A. D.; WILSON, B. A.; WATTS, F. N. (1995). Handbook of memory disorders. Sussex: Wiley.

BARGH, J. (2017). Before You Know It: The Unconscious Reasons We Do What We Do. New York: Simon \& Schuster.

BAUMEISTER JC; FORONI, F; CONRAD, M; RUMIATI, R. I.; WINKIELMAN; P. (2017). Embodiment and Emotional Memory in First vs. Second Language. Frontiers in Psychology, 8:394. DOI: 10.3389/fpsyg.2017.00394 
BENESCH, S (2011). Considering emotions in critical English-language teaching: Theories and praxis. London, UK: Routledge.

BISQUERRA ALZINA, R. (2003). Educación emocional y competencias básicas para la vida. Revista de Investigación Educativa, 21(1), 7-43.

BOND, M.; LAI, T-M. (1986). Embarrassment and code-switching into a second language. The Journal of Social Psychology, 126 (2), 179-186.

BOZA, N. (2002). Un aspecto de la inteligencia intrapersonal: la autoeficacia en el aula de inglés. En C. FONSECA, (ed.), Inteligencias múltiples, múltiples formas de enseñar inglés. Sevilla: Mergablum.

BRANSFORD, J.; BROWN, A; COCKING, R. (2003). How People Learn: Brain, Mind, Experience, and School. National Academy Press.

BUCCINO, G.; RIGGIO, L.; MELLI, G.; BINKOFSKI, F.; GALLESE, V. \& RIZZOLATTI, G. (2005). Listening to action-related sentences modulates the activity of the motor system: a combined TMS and behavioral study. Brain research. Cognitive brain research, 24(3), 355-63. DOI: 10.1016/j.cogbrainres.2005.02.020

CALDWELL-HARRIS, C. L.; AYCICEGI-DINN, A. (2009). Emotion and Lying in a NonNative Language. International Journal of Psychophysiology, 71, 193-204. DOI: 10.1016/j.ijpsycho.2008.09.006

CALVO, P.; GOMILA, A. (2008). Handbook of Cognitive Science: An Embodied Approach. Elsevier.

CARLSON, N. R. (1996). Fundamentos de Psicología Fisiológica, 3.a ed. Prentice Hall.

CARRETIÉ, L. (2011). Anatomía de la mente. Emoción, cognición y cerebro. Madrid: Ediciones Pirámides.

DAMASIO, A. (1994). Descartes' Error: Emotion, Reason and the Human Brain. Pan Macmillan.

DAMASIO, A. (1998). The Feeling of What Happens: Body and Emotion in the Making of Consciousness. New York: Harcourt Brace \& Company.

DAMASIO, A. (2010). Self comestomind: constructing the conscious brain. New York: Pantheon Books.

DE ANDRÉS, V. (2000). La autoestima en el aula o la metamorfosis de las mariposas. In J. ARNOLD (ed.), La dimensión afectiva en el aprendizaje de idiomas (105-126). Madrid: Cambridge University Press.

DE GRAUWE, S.; WILLEMS, R. M.; RUESCHEMEYER, S.A.; LEMHÖFER, K., \& SCHRIEFERS, H. (2014). Embodied language in first- and second-language speakers: Neural correlates of processing motor verbs. Neuropsychologia, 56, 334-349. DOI: 10.1016/j.neuropsychologia.2014.02.003 
DE VEGA, M. (2005). Lenguaje, corporeidad y cerebro: Una revisión crítica. Revista Signos, 38(58), 157-176. DOI: 10.4067/S0718-09342005000200002

DEWAELE, J. M. (2004). Perceived language dominance and language preference for emotional speech: the implications for attrition research. In M. S. SCHMID; B. KÖPKE; M. KEJSER; L. WEILEMAR (eds.), First Language Attrition: Interdisciplinary Perspectives on Methodological Issues (pp. 81-104). Amsterdam/Philadelphia: John Benjamins.

DEWAELE, J-M. (2008). The emotional weight of I love you in multilinguals' languages. Journal of Pragmatics, 40 (10), 1753-1780. DOI:10.1016/j.pragma.2008.03.002

DEWAELE, J.-M.; PAVLENKO, A. (2002). Emotion vocabulary in interlanguage. Language Learning, 52, 265-324. DOI: 10.1111/0023-8333.00185

DI PAOLO, E. (2015). Interactive time-travel: On the intersubjective retro-modulation of intentions, Journal of Consciousness Studies, 22 (1-2), 49-74.

DÖRNYEI, Z. (2005). The Psychology of the Language Learner: Individual Differences in Second Language Acquisition. Mahwah, NJ: Lawrence Earlbaum.

DÖRNYEI, Z.; MURPHEY, T. (2003). Group Dynamics in the Language Classroom. Cambridge: Cambridge University Press.

FISCHER, M. H., \& ZWAAN, R. A. (2008). Embodied language: A review of the role of motor system in language comprehension. The Quarterly Journal of Experimental Psychology, 61(6), 825-850. DOI: 10.1080/17470210701623605

FORONI, F. (2015). Do we embody Second Language? Evidence for 'partial' simulation during processing of a second language. Brain and Cognition, 99, 8-16. DOI: 10.1016/j.bandc.2015.06.006

FORONI, F.; SEMIN, G.R. (2013). Comprehension of action negation involves inhibitory simulation. Frontiers in Human Neuroscience, 7(209), 1-7. DOI: 10.3389/fnhum.2013.00209

FREEMAN, W. J. (2000). Emotion is essential in all intentional behaviors. In: M. D. LEWIS and I. GRANIE, I. (eds.), Emotion, development and self-organitzation dynamic system approaches to emotional development (pp. 209-235). Cambridge: Cambridge University Press.

FUSTER, J. (1995). Memory in the Cortex. Cambridge: MIT Press.

FUSTER, J. M. (2014). Cerebro y Libertad: los cimientos cerebrales de nuestra capacidad para elegir. Barcelona: Editorial Planeta.

GARCÍA, A.; SUÁREZ, S. (eds.) (2016). Mente bilingüe. Abordajes psicolingüísticos y cognitivistas. Córdoba: Comunicarte.

GIMÉNEZ AMAYA, J. M.; MURILLO GÓMEZ, J. (2007). Mente y cerebro en la Neurociencia contemporánea. Una aproximación a su estudio interdisciplinar. Scripta Theologica, 39 (2), 607-636. 
GLENBERG, A. M. \& KASCHAK, M. P. (2002). Grounding language in action. Psychonomic Bulletin \& Review, 9(3), 558-65. DOI: 10.3758/bf03196313

GLENBERG, A.; DE VEGA, M.; GLAESSER, A. (2008). Symbols and embodiment. Oxford: Oxford University Press.

GOLDMAN-RAKIC, P. S. (1999). The physiological approach: functional architecture of working memory and disodered cognition in schizophrenia. Biol Psychiat, 46, 650-661. DOI: 10.1016/s0006-3223(99)00130-4

GONZÁLEZ ÁLVAREZ, J. (2007). Brain and Language: The Neural Representation of Words and their Meanings. In III Conference ALFAL-NE. Invited speech. Oxford: Oxford University Taylor Institution.

GONZÁLEZ-REIGOSA, F. (1976). The anxiety-arousing effect of taboo words in bilinguals. In C. D. SPIELBERGER and R. DÍAZ-GUERRERO (eds.) Cross-Cultural Anxiety (pp. 89-105). Washington, DC: Hemisphere.

GONZÁlEZ, J.; BARROS-LOSCERTALES, A.; PULVERMÜllER, F.; MESEGUER, V.; SANJUÁN, A.; BELLOCH, V.; ÁVILA, C. (2006). Reading cinnamon activates olfactory brain regions. NeuroImage, 32, 906-912.

HARRIS, C. L., AYÇIÇEĜI, A.; GLEASON, J. B. (2003). Taboo words and reprimands elicit greater autonomic reactivity in a first language than in a second language. Applied Psycholinguistics, 24(4), 561-579. DOI: 10.1017/S0142716403000286

HARRIS, C. L., GLEASON, J. B.; AYCICEGI, A. (2006). When is a first language more emotional? Psychophysiological evidence from bilingual speakers. In A. PAVLENKO (ed.), Languages and emotions of bilingual people (pp. 257-283). Clevedon: Multilingual Matters.

HASCHER, T. (2010). Learning and Emotion: Perspectives for Theory and Research. European Educational Research Journal, 9(1), 13-28. DOI:10.2304/eerj.2010.9.1.13.

HAUK, O., JOHNSRUDE, I.; PULVERMÜLLER, F. (2004). Somatotopic representation of action words in human motor and premotor cortex. Neuron, 41(2), 301-7. DOI: 10.1016/s0896-6273(03)00838-9

HAUK, O.; SHTYROV, Y. \& PULVERMÜLLER, F. (2008). The time course of action and action-word comprehension in the human brain as revealed by neurophysiology. Journal of Physiology, 102(1-3), 50-8. DOI:10.1016/j.jphysparis.2008.03.013

HINTZMAN, D. L. (1986). 'Schema abstraction' in a multiple-trace memory model. Psychological Review, 93(4), 411-428. DOI: 10.1037/0033-295X.93.4.411

HUTH, A.; DE HEER, W.; GRIFFITHS, T.; THEUNISSEN, F; GALLANT, J. (2016). Natural speech reveals the semantic maps that tile human cerebral cortex. Nature, 532(7600), 453-458. DOI: 10.1038/nature 17637 
ISURIN, L. (2017). Collective remembering: Memory in the world and in the mind. Cambridge: Cambridge University Press.

KAHNEMAN, D. (2011). Thinking, fast and slow. Farrar, Straus and Giroux.

KAUSHANSKAYA, M.; MARIAN, V. (2008). Nontarget language recognition and interference in bilinguals: Evidence from eye tracking and picture naming. Language Learning, 57 (1), 119-163. DOI: 10.1111/j.1467-9922.2008.00455.x

KRAMSCH, C. (2009). The multilingual subject. What foreign language learners say about their experiences and why it matters. Oxford: Oxford University Press.

LEWIS, M. D. (2005). Bridging emotion theory and neurobiology through dynamic systems modeling. Behavioral and Brain Sciences, 28, 105-131, 2005. DOI: $10.1017 / \mathrm{s} 0140525 \mathrm{x} 0500004 \mathrm{x}$

LIBET, B. (1985). Unconscious cerebral initiative and the role of conscious will in voluntary action. Behavioral and Brain Sciences, 8, 529-539. DOI: 10.1017/S0140525X00044903

LORENZO, F. (2004). La motivación y el aprendizaje de una L2/LE. In: J. SÁNCHEZ and I. SANTOS (eds.), Vademécum para la formación de profesores. Enseñar español como segunda lengua /lengua extranjera (305-328). Madrid: SGEL.

MACINTYRE, P.; CHAROS, C. (1996). Personality, attitudes and affect as predictors of second language communication. Journal of Language and Social Psychology, 15 (1), 3-26.

MACKNIK, S.; MARTINEZ-CONDE, S.; BLAKESLEE, S. (2010). Sleights of Mind: What the Neuroscience of Magic Reveals About Our Everyday Deceptions. Nueva York: Henry Holt and Co.

MACWHINNEY, B. (2001). The competition model: The input, the context, and the brain. In ROBINSON, P. (ed.), Cognition and Second Language Instruction (Cambridge Applied Linguistics, pp. 69-90). Cambridge: Cambridge University Press.

MARIAN, V.; KAUSHANSKAYA, M. (2004). Self-construal and emotion in bicultural bilinguals. Journal of Memory and Language, 51(2), 190-201. DOI: 10.1016/j.jml.2004.04.003

MARIAN, V.; NEISSER, U. (2000). Language-dependent recall of autobiographical memories. Journal of Experimental Psychology: General, 129(3), 361-368, 2000. doi: 10.1037//0096-3445.129.3.361

MARTIN, A; HAXBY, J.V.; LALONDE, F.M.; WIGGS, C.L.; UNGERLEIDER, L.G. (1995). Discrete cortical regions associated with knowledge of color and knowledge of action. Science, 270, 102-105. DOI: 10.1126/science.270.5233.102

METEYARD, L.; CUADRADO, S. R.; BAHRAMI, B. \& VIGLIOCCO, G. (2012). Coming of age: a review of embodiment and the neuroscience of semantics. Cortex, 48(7), 788804. DOI: 10.1016/j.cortex.2010.11.002 
MORA, F. (2013). ¿Qué es una emoción? Arbor, 189 (759), a004. DOI: 10.3989/arbor.2013.759n1003.

MORA, F. (2017). Neuroeducación. Solo se puede aprender aquello que se ama. Madrid: Alianza Editorial.

MOSELEY, R.; CAROTA, F.; HAUK, O.; MOHR, B. \& PULVERMÜLLER, F. (2012). A role for the motor system in binding abstract emotional meaning. Cerebral Cortex. 22(7):1634-47. DOI: 10.1093/cercor/bhr238

NOË, A. (2010). Fuera de la cabeza. Barcelona: Kairó.

PAVLENKO, A. (1998). Second language learning by adults: Testimonies of bilingual writers. Issues in Applied Linguistics, 9 (1), 3-19.

PAVLENKO, A. (2002). Bilingualism and emotions. Multilingua, 21 (1), 45-78. DOI: $10.1515 /$ mult.2002.004

PAVLENKO, A. (2005). Bilingualism and Thought. In A. DE GROOT and J. F. KROLL (eds.) Handbook of Bilingualism: Psycholinguistic Approaches (pp. 433-453). Oxford: Oxford University Press.

PETRIDES, M. (2000). Dissociable roles of mid-dorsolateral prefrontal and anterior inferotemporal cortex in visual working memory. The Journal of Neuroscience, 20(19), 7496-7503. DOI: 10.1523/JNEUROSCI.20-19-07496.2000

POSNER, M.; ROTHBART, M. (2005). Influencing brain networks: implications for education. Trends in Cognitive Sciences, 9 (3), 99-103. DOI: 10.1016/j.tics.2005.01.007

PRESTON, C. (2013). The role of distance from the body and distance from the real hand in ownership and disownership during the rubber hand illusion. Acta Psychol (Amst), 142 (2), 177-83.

PULVERMÜLLER, F. (2005). Brain mechanisms linking language and action. Nature Reviews Neuroscience, 6: 576-582. DOI: 10.1038/nrn1706

PULVERMÜLLER, F.; FADIGA, L. (2010). Active perception: sensorimotor circuits as a cortical basis for language. Nat Rev Neurosci, 11(5), 351-360. DOI: $10.1038 / \mathrm{nrn} 2811$.

PULVERMÜLLER, F.; PREISSL, H.; LUTZENBERGER, W.; BIRBAUMER, N. (1996). Brain rhythms of language: nouns versus verbs. European Journal of Neuroscience, 8, 937-941. DOI: 10.1111/j.1460-9568.1996.tb01580.x

QUENÉ, H., SEMIN, G. R. \& FORONI, F. (2012). Audible smiles and frowns affect speech comprehension. Speech Communication, 54(7), 917-922. DOI: 10.1016/j.specom.2012.03.004

RUBIA, F. (2000). El cerebro nos engaña. Temas de Hoy. 
RUBIA, F. (2009). El fantasma de la libertad. Anales de la Real Academia Nacional de Medicina, 3, 377-388.

RUBIO, F. D. (2004). La ansiedad en el aprendizaje de idiomas. Huelva: Servicio de Publicaciones de la Universidad de Huelva.

SAAVEDRA J.; DÍAZ W,; ZÚÑIGA L.; NAVIA C.; ZAMORA T. (2015). Correlación funcional del sistema límbico con la emoción, el aprendizaje y la memoria. Morfolia, 7 (2), 29-44.

SCHERER, K. R. (1984). Emotion as a multicomponent process: A model and some crosscultural data. Review of Personality \& Social Psychology, 5, 37-63.

SCHERER, K. R. (2005). What are emotions? And how can they be measured? Social Science Information, 44(4), 695-729. DOI:10.1177/0539018405058216

SCHRAUF, R. W. (2000). Bilingual autobiographical memory: Experimental studies and clinical cases. Culture \& Psychology, 6(4), 387-417. DOI: $10.1177 / 1354067 X 0064001$

SCHRAUF, R. W.; RUBIN, D. C. (1998). Bilingual autobiographical memory in older adult immigrants: A test of cognitive explanations of the reminiscence bump and the linguistic encoding of memories. Journal of Memory and Language, 39(3), 437457. DOI: $10.1006 /$ jmla.1998.2585

SEMIN, G. R.; SMITH, E. R. (eds.). (2008). Embodied grounding: Social, cognitive, affective, and neuroscientific approaches. Cambridge University Press.

SOON, CH.S.; BRAAS, M.; HAYNES, J.D. (2008). Unconscious determinants of free decisions in the human brain. Nature Neuroscience, 11, 543-545. DOI: $10.1038 / \mathrm{nn} .2112$

STEVICK, E. (1998). Working with Teaching Methods. What's at Stake? Pacific Grove: Heinle \& Heinle.

SUTTON, L.; SMITH, N.; DEARDEN, C.; MIDDLETON, S. (2007). A child's-eye view of social difference. Loughborough University. Online resource. (https://hdl.handle.net/2134/3045). [Consultado el 20/06/2021]

TOMASINO, B.; RUMIATI, R. I. (2013). At the mercy of strategies: the role of motor representations in language understanding. Front Psychol, 4, 27. DOI: 10.3389/fpsyg.2013.00027

TULVING, E.; THOMSON, D. M. (1973). Encoding specificity and retrieval processes in episodic memory. Psychological Review, 80(5), 352-373. DOI: $10.1037 / \mathrm{h} 0020071$

WILLIAMS, M.; BURDEN, R. (1999). Psicología para profesores de idiomas. Madrid: Cambridge University Press.

WINKIELMAN, P.; NIEDENTHAL, P. M. \& OBERMAN, L. (2008). The embodied emotional mind. In G. R. SEMIN and E. R. SMITH (eds.), Embodied grounding: Social, 
cognitive, affective, and neuroscientific approaches (pp. 263-288). Cambridge University Press.

YOUNG, D. J. (1999). Affect in Foreign Language and Second Language Learning: A Practical Guide to Creating a Low-anxiety Classroom Atmosphere. New York: McGraw-Hill.

ZULL, J. (2002). The Art of Changing the Brain: Enriching the Practice of Teaching by Exploring the Biology of Learning. Stylus Publishing.

ZWAAN, R. A. \& TAYLOR, L. J. (2006). Seeing, acting, understanding: Motor resonance in language comprehension. Journal of Experimental Psychology: General, 135(1), 1-11. DOI: /10.1037/0096-3445.135.1 